Siberian economy today, and R. North tackles the problems facing the developmentof a comprehensive transport-communications network over the vast, sparselypopulated distances. Special attention is devoted by V. Conolly to the newly-constructed Baykal-Amur railway. J. Erickson's chapter on military and strategic factors I found weaker than its counterpart in Swearingen's booka Who's Who of the Eastern Theatre rather than a synthesis of the historical geography of conflict along disputed borders with China and Japan. However, Wood's collection ends strongly with a summary by S. Kirby of Siberia's relations with its Asian neighbours, and a look by J. Stephens at past and potential involvement of Siberia in the world economy. This excellent survey of Siberia is enriched by maps and good bibliographies at the end of each chapter. Chapters contain frequent cross-references to each other, enhancing the book's integrity.

Swearingen aims at more specific themes-the 'guns over growth' trend of Siberian development and its implications for regional security and potential trade relationships. Some of the essays address this theme directly; others, while providing solid scholarship, touch on it more tangentially. Stricter editing could have enhanced the continuity and thematic cohesiveness of this work. V. Conolly (the only contributor to both volumes) provides a lively introduction to the environment and resources, including population, of Siberia. V. Mote contributes an informative and highly readable chapter on transport and communications. Energy industries are covered by $\mathrm{T}$. Gustafson; M. Bradshaw analyzes the regional impact of trade and technology transfer in the Soviet economy, with special emphasis on Siberia. W. Czernieijewisz's treatment of economic linkages with Europe takes a while to home-in on Siberian trade, and would have benefitted from editorial contraction, but provides a useful analysis of the Siberian-Western European Gas Project. K. Ogawa discusses Siberian-Japanese trade, painting a darker picture of prospects for the future than does Kirby in Wood's volume, who refers to relationships between these two partners as 'extremely portentious'. H. Gelman gives a good overview of the military build-up in Siberia-the 'Pacific Shift' in Soviet troops and ordnance, rich in historic detail. In his chapter on strategic dimensions in the Pacific arean, Swearingen elaborates on the significance of this build-up.

Especially commendable in Swearingen's book is the final chapter by P. Polansky on resources for research on Siberia, a terse yet invaluable guide providing a refreshing variation to the more-often proffered 'Further Reading' appendix. Listing bibliographies, journals, newspapers, institutes, libraries and publishing houses of vital interest to the student of Siberia, it is an example that more editors might follow. One grins at the minor editorial slipConolly's too-literal translations of Russian buzzwords, Mote's amusing entry of 'Not available' for data on passenger transport by pipeline in Table 2.2. One grimaces at Swearingen's summary dichotomy of 'peace- loving nations' versus the Soviet Union (p257), though by this juncture one has already caught on to the biases behind the book.

Wood's volume is the more useful and more readable for a general audience, and a valuable basic text for students of Soviet and northern geographty and history. Swearingen's book, narrower in intent, caters to specialized interests, but also provides embellishing material and analysis complementary to Wood's offerings. Both should be read by those interested in Siberia. (Gail Fondahl, Department of Geography, University of California, Berkeley, California, USA.)

\section{SCENIC ANTARCTICA}

SHIP IN THE WILDERNESS. Snyder, J. and Shackleton, K. 1986. London, Dent. 208 p, illustrated, hard cover. ISBN 0-460-04719-1. £14.95.

WILDLIFE AND WILDERNESS: AN ARTIST'S WORLD. Shackleton, K. 1986. London, Clive Holloway Books. $120 \mathrm{p}$, illustrated, hard cover. ISBN 0907745-06-7. £15.00

The first of these two outstanding books, subtitled 'Voyages of the MS Lindblad Explorer through the last wild places on Earth', covers the travels of a famous cruise ship to out-of-the-way places including the Aleutian Islands, Bering Strait, the Northwest Passage, Iceland, Greenland and Svalbard, several islands of the Southern Ocean fringe, and both East and West Antarctica. Jim Snyder's photography is superb, Keith Shackleton's illustrations and warm commentary are a blessing, the production is faultless and the price unbelievable. For those who prefer their Shackleton undiluted I no less strongly recommend the second. This too is the result of the artist's travels for 15 years as naturalist aboard Lindblad Explorer. Whoever thought up that job for him did the world a service. Keith Shackleton's enthusiasm and love for polar animals and scenes is patent in both the text and the marvellous pictures; I know no other writer or painter who catches the polar world so neatly. The last few years have brought many books covering the polar regions in black, white and colour. These are among the best-good value for the armchair traveller, and powerfully evocative for those who have been there. If you cannot manage a polar cruise, they may serve as the next best thing. (Bernard Stonehouse, Scott Polar Research Institute, Lensfield Road, Cambridge CB2 1ER.)

\section{ENGINEERING FOR PERMAFROST}

PIPELINES AND PERMAFROST: SCIENCE IN A COLD CLIMATE. Williams, P. J. 1987. Ottawa, Carleton University Press. 129 p, illustrated, soft cover. ISBN 0-88629-056-2. Can $\$ 9.95$.

This is a study of northern pipelines in Canada and Alaska. It concentrates on the geotechnical aspects of the projects, 